Article

\title{
Infrastructure Is Key to Make Cities Sustainable
}

\section{Michael Neuman}

School of Architecture and Cities, University of Westminster, London NW1 5LS, UK; m.neuman@westminster.ac.uk

Received: 27 August 2020; Accepted: 1 October 2020; Published: 9 October 2020

\begin{abstract}
Infrastructure is all around us: under, above, even inside our built and natural landscapes. Sometimes hidden, sometimes visible. The flows that course through them make our cities, economies, and lives possible. Cities could not even exist without infrastructure. Life is endowed with more possibilities by infrastructure. The centrality of infrastructure is pervasive. Worldwide, cities embrace infrastructure for economic competitiveness, well-being, access, environmental protection and knowledge creation. As cities are crucibles that concentrate the human condition, infrastructures are conduits that enable that concentration and empower human achievement. As infrastructures shape almost every aspect of daily life, this article assays the various ways it currently makes places both less sustainable and resilient, as well as more so, and how we can minimise the former and optimise the latter.
\end{abstract}

Keywords: infrastructure; capital facilities; community services; public realm; sustainability; resilience; planning; design; finance; governance

\section{Introduction}

Infrastructure is all around us: under, above, even inside our built and natural landscapes. Sometimes hidden, becoming "visible" when not working. Sometimes visible, whether beautiful like the Golden Gate Bridge, or not, like most mobile phone towers. The flows that course through them make our cities, economies, and lives possible. Cities could not even exist without infrastructure. The more powerful their infrastructures-and their hidden flows-then the more powerful the city and the economy. Life is endowed with more possibilities by infrastructure.

The centrality of infrastructure is pervasive. Worldwide, cities embrace infrastructure not only for economic competitiveness. Issues across the board, from well-being and access to environmental protection and knowledge creation, fall squarely in the realm of infrastructure. As cities are crucibles that concentrate the human condition, infrastructures are conduits that enable that concentration and empower human achievement.

Infrastructures shape almost every aspect of daily life for all of us, and not just humans. Consider their impacts on ecosystems far and wide, on the entire earth system, and on most if not all species. Our decisions and actions regarding infrastructure have long term (millennial) and wide-ranging effects. The effects of infrastructure are multi-fold. They connect, enable, support, maintain, protect, enhance, and enrich. They also can destroy, divide, hamper, impinge, and make us dependent. After the sun, sea, and soil, infrastructures could be the most consequential factor in life on earth, as far as humans are concerned.

In pre-industrial societies, which we could call truly sustainable societies in terms of energy, materials, and environmental impacts; infrastructures were largely powered by the sun, wind, water, and gravity. Think of daylight, windmills, canals, aqueducts, rivers, watermills, and dams. Travel was on mediums also powered by water and wind, or animals and humans, without fossil fuels. They were built with sustainable and natural materials. The principles underlying those sustainable 
infrastructures are relevant today, even as we cannot go backwards in history nor should we idealise historical societies. New infrastructures that have their own principles and properties will also be surveyed. Novel advancements in infrastructure transform our lives, cities, and planet in ways beyond our control. Their scale, scope, and magnitude can overwhelm individuals and ecosystems, and seem out of our individual control. In many instances, this causes dependence and despondence, leading to unintended adverse effects to health physical and mental. They can disconnect humans from nature, leading to emotional and spiritual maladies. Given the multi-fold effects of infrastructures, how can we plan, design, and build them so that good outweighs bad, beauty overtakes ugly?

The scale, scope, and ubiquity of infrastructure is an unsung hero and antihero in our world, most definitely for better and for worse. While the intent behind all infrastructure is to abet the greater good, at least in principle, the reality has become quite removed from that. Infrastructures have become a double-edged sword, cogently analysed in a landmark book Splintering Urbanism [1]. Another potential landmark, The Promise of Infrastructure, provides more recent scrutiny of the same dilemmas, across new terrains [2].

Let us take a closer look at how these multilemmas play out by assaying a few megastructures designed to protect coastlines and low-lying interior cities and lands. One the one hand, they provide needed "insurance" against potentially catastrophic flooding, storm surges, and sea level rise. The value of what is being protected far exceeds the multi-billion monetary costs of these gargantuan projects that were unthinkable not long ago. From a short or even medium term economic and social calculus, they make perfect sense. Their cost-benefit ratio in simple economic terms is almost unassailable.

On the other hand, credible and increasingly likely projections state that greenhouse gas concentrations in the atmosphere and average global surface temperatures will reach $500 \mathrm{ppm} \mathrm{CO}_{2}$ and three to five degrees Celsius above today, respectively. Given that historic sea levels, when temperatures and $\mathrm{CO}_{2}$ levels were that high, were twenty or more meters higher than today $[3,4]$-how well will these coastal infrastructures protect us in the future? The Late Eemian interglacial period, about 115,000 years ago, with the highest temperatures known in the homo sapiens era, of two degrees C. greater than today, had observed sea levels between six to nine meters higher than the present $[5,6]$ Will contemporary flood barriers lull us complacently into inaction or inadequate action with their short term promises of safety? [7] show how gross underestimates of coastal flooding reveal that low-lying coastal cities and regions will be flooded within our lifetimes, causing hundreds of millions of climate refugees from this source alone.

\section{Infrastructure Hubris}

Ahkil Gupta eloquently marks this nature of infrastructure and how it affects thought and action in his phrase "the future in ruins", where he refers to the "temporality of infrastructure" [8]. In other words, can we afford to be so short-sighted about the long term impacts of infrastructures in the face of a radically different and perhaps unrecognisable world within the next generation?

Other examples of infrastructure hubris abound. The Thames Barrier, opened in 1982 at a cost of a half a billion pounds (GBP 2 billion today), spans 520 metres across the River Thames in London. It is designed to protect approximately 125 square kilometres of central London from flooding caused by tidal surges. The Delta Works-the storm surge barrier that protects the Netherlands from flooding-was initiated after the 1953 North Sea flood and was completed in 1997 at a cost of 8 billion Dutch guilders, about USD 4 billion then [1]. The latest project for the North Sea is a deep-sea barrier called NEED—the Northern European Enclosure Dam - stretching from southern Norway to Scotland (300 miles), and southern England to France (100 miles). According to the scientists who wrote the paper proposing it, it could cost anywhere from USD 250 billion to USD 550 billion. There are other existing sea barrier megaprojects around the world, such as nearly-completed MOSE (MOdulo Sperimentale Elettromeccanico, Experimental Electromechanical Module). Intended to protect Venice, Italy, it is estimated to cost upwards of USD 6 billion [9]. The 21 mile long Saemangeum Seawall in 
Korea, completed in 2010 at a cost of over USD 2 billion, at an average height of 118 feet, may have a better chance to be effective over the long run [10].

These projects are but a tip of the iceberg when it comes to protection from storm flooding and sea level rise globally. Current projections suggest that they will not be adequate to hold back the sea in the face of catastrophic impacts from global warming. Yet these cautionary tales convey the audacity, of hope, technology, ambition, and hubris that humans still take in attempts to control nature. This control is most often through infrastructure. Yet this "control" is mostly an illusion, with short term and partial gains at best. Most likely, is long term damage at a larger scale with greater consequences [11].

If this was not enough, consider what happened in Australia in their summer of 2020. In the wake of a long severe draught, bush fires devastated tens of millions of acres, caused over a hundred billion dollars in property damage, with estimates of a billion animals killed along with at least thirty humans. As they country reeled in shock, one local aptly asked "How do you adapt when the changes coming are not simply new patterns but the very loss of a predictable pattern? How do you adapt to chaos? How do you affordably prepare a home simultaneously for drought, wind, rain, smoke, dust, fire, blackouts, rising sea levels, falling trees, floods, hail and record-breaking temperatures?"

These examples of sea control are merely one way to portray the dual nature and the multiple dilemmas that are part and parcel of all infrastructures. They all cut across, quite literally, places and peoples in different ways at different times. The same infrastructure might be a boon when it began service, yet may become a burden over time. This can be seen with dams on rivers, cars on roads, and toxic electronic devices in landfills. An infrastructure might benefit some populations and harm others, depending on how they are managed, such as schools and courts. Without universal access to learning and without fair adjudication of justice, some populations are disadvantaged. The question is, can we design, build, and operate infrastructures so that they do not cut both ways, good and bad? I posit that the answer is yes, or at least it can closely approach yes. This can be done by taking the long view and assessing all the foreseeable consequences over the full life span of any infrastructure, including its repurposing and/or recycling. Thus, planners, designers, and policy makers can make better decisions for truly sustainable and resilient infrastructure.

To accomplish this, the central role of cities to infrastructure, and in particular their sustainability, must be considered. This is essential for proper their planning and design. Not understanding and acting on the mutual interaction of cities and infrastructures will only continue to hinder sustainability efforts. It is argued that making infrastructure sustainable is the key to the sustainable city. This premise has been known to civilisations for millennia because it was vital to their growth and survival.

Cities are humankind's crowning achievements. Cities are the largest and most complex artefacts created by humans. Their size and complexity bear directly on the very possibility of their sustainability. "Cities are the most visible signature of the Anthropocene: a new era in the co-evolution of life and the planet." This, from her book Cities That Think Like Planets, Marina Alberti underscores a new condition of our age, and of the evolution of life on our planet [2]. If Sir David Attenborough has another series left in him to crown his quest to inform and inspire, he would do well to call it the Grey Planet, and address cities, the source of pressure on the species and planet he cares so much about.

Professor Alberti goes on to say that "Urban ecology faces a significant challenge: to position itself in the context of planetary change and to understand the role that cities play in the evolution of the earth" [2]. To understand the role of cities in evolution of the earth and its ecosystems, knowing infrastructures is key. Cities themselves are ecosystems and infrastructures are their roots. Without infrastructure, cities simply could not exist. Infrastructures are the lifeblood and circulatory systems of urban ecosystems. This way, we realise that urban metabolism and function extend far beyond the city limits and its hinterlands. Cities are connected globally and are the outposts and command posts of globalisations [12]. City ecologies and their metabolisms are based on, and can be estimated by proxy, via infrastructure flows and processes (An early effort was led by a team from the Australian National University, which analysed Hong Kong in the 1970s. They chose Hong Kong, 
a global city even then, as a city, state, and island; they believed it was easy to calculate what happened within its city limits. Today we know that it is difficult if not impossible to estimate precisely for an individual city, because of the interconnections manifest by globalization. See [13]). Moreover, city regions form new hybrid ecosystems with rural and natural areas as they increasingly intertwine. Furthermore, many infrastructures, especially telecommunications and transport, but also energy and education, for example, are more than the roots of urban and extended hybrid ecosystems. They criss-cross the globe and enable globalisation. Indeed, infrastructure literally undergirds virtually all human endeavours.

Yet as cities explode in size and population, their infrastructures tend not to keep pace with urban needs and human desires, resulting in inadequate service, illness, disease, pollution, poverty, and so on. While cities and economies generate wealth, infrastructures are often underfunded and thus deteriorate. The reasons are multi-fold, stemming from neoliberalism and its concomitant devaluing of the public sector and public services. This steady draw down of governments' ability to raise funds to pay for infrastructure applies to its entire lifecycle of planning, design, operation, repair, replacement, and recycling. In this context, while awareness and understanding of the importance of infrastructure is high, the political will to fund actual investments is low and going lower, considering infrastructure spending as a percentage of GDP [14]. This trend is ongoing, since around 1980 [15].

We see report upon report extolling the virtues while simultaneously decrying the condition and inadequacies of our infrastructure. In the United Kingdom, the Eddington and Armitt Reports, the Institute of Civil Engineers, the Royal Town Planning Institute, the London Infrastructure Plan 2050, government agencies, foundations, think tanks, and others have chimed in. In this avalanche, London and the United Kingdom are far from alone. In the United States, the American Society of Civil Engineers produces a quadrennial "report card" of the national conditions, State of America's Infrastructure Report Card. The last was most alarming yet. It gave an overall grade for all infrastructures as a D+, just above failing [16]. The report's authors calculated that the cost to bring to American infrastructure to current standards over the next eight years was USD 4.5 trillion-not accounting for new growth, new technologies, and raising standards, including sustainability and equitable access. Many nations have their equivalents, as do international bodies, notably the World Bank, the International Monetary Fund, the United Nations and the Organisation for Economic Cooperation and Development.

Given all this expertise and capacity, we have the knowledge to deal with these issues. To cite Sir John Armitt, Chair of the National Infrastructure Commission in the UK: "A second engineering adage comes to mind: "give me a problem and I will give you a solution". We are good at engineering solutions, but we don't always fully examine the root cause of the problem" [17]. Let me offer an urban planning counterpart. Give me a problem and we will give you an analysis of the root causes. This suggests that planners, designers, and engineers should work together more often, as they do in cities like Barcelona. This has implications for education as well as for policy and finance $[18,19]$.

To know infrastructure, one first must know cities. To know cities, one must know infrastructure. Infrastructurists must be urbanists, and vice versa. Moreover, urban designers and planners see the long term and the big picture, design future scenarios, examine impacts, and develop assessment tools, while considering multiple interests in multiple contexts at multiple scales. Putting infrastructure, cities, and urbanisation trends together in historical context illustrates how infrastructures begot the urban explosion as well as enabled massive consumption increases to go along with this explosion. In our wasteful world, consumption equals waste, by-products, and pollution. That is, the opposite of sustainability. Can infrastructure be retooled to support degrowth [20]?

To appreciate this, ponder the scale and pace of urbanisation today by comparing it to population, economy, and energy increases since the year 1500. "In the year 1500, there were about 500 million Homo sapiens in the entire world. Today, there are almost 8 billion, (fourteen-fold increase). The total value of goods and services produced by humankind in the year 1500 is estimated at USD 250 billion, in today's dollars. Nowadays the value of a year of human production is (over USD 80) trillion, (320-fold jump). 
In 1500, humanity consumed about 13 trillion calories of energy per day. Today, we consume 1500 trillion calories a day (115-fold rise)" [21]. According to my own calculations based on UN, IEA, CIA, and World Bank data since 1960, while the human population has more than doubled, global economic output has octupled, and resource consumption gone up even more (Estimates on resource depletion vary). Thus, we are getting less efficient and less sustainable as we move to cities, not more, contrary to popular belief and professional dogma. Cities are voracious.

Prospects for the future are worse. A 2016 UN Environment Programme report projects world resource consumption will triple by 2050 , even as world population will rise only by 28 percent [22]. Where will this end, if nearly 50 years ago we already exceeded the planet's natural capacity to support our presence [23]?

In 1997, a number of preeminent ecologists and biologists published a linked series of studies in a special issue of Science titled Human Dominated Ecosystems. They provided evidence that every habitat, Antarctica included, is dominated by human activities. Ten years before that ecologist Eugene Stoermer coined the term Anthropocene [24]. The Anthropocene is our present epoch that gives a name to human modifications to the biosphere. Per Benjamin Kunkel, it is the current situation "in which humanity, accidentally or deliberately, engineers the planet's condition" [25]. More and more scientists predict global collapse this century due to complete marine algae die-off at 500 parts per million of $\mathrm{CO} 2$ in the atmosphere, which at current rates will occur in 2050, assuming an average 3 ppm annual increase over that period, and a base of $418 \mathrm{ppm}$ in 2020.

We know from numerous studies that causes and consequences are not distributed evenly. For example, Andreas Malm in Fossil Capital highlights that "In the early 21st century, the poorest 45 per cent of humanity generated 7 per cent of $\mathrm{CO}_{2}$ emissions, while the richest 7 per cent produced 50 per cent." Capital is more implicated than carbon [26]. This, along with potentially hundreds of millions of climate refugees and potential food shortages associated with increasing, and increasingly severe, droughts, means that the climate crisis is a humanitarian crisis as well as an ecological one.

\section{The Power of Flows}

Manuel Castells claimed over thirty years ago that the flows of power had been overtaken by the power of flows (Castells 1989), an endorsement of the power of infrastructure. The virtual world of digital flows has overtaken the tangible world of historic and longstanding institutions. Digital flows of capital and information, whether programmed ones in capital markets and commerce, or random ones across social media, overwhelm long standing power structures and render them far less than effective than before. This has fuelled the ungovernability crisis, in part, both in terms of political chaos and the private sector overwhelming the public sector [27]. If infrastructure sowed, and accelerated, the seeds of our production, and later destruction, can we invert the equation to find in flows-and their conduits, infrastructure-a salvation that is cleaner, greener, and more equitable?

Let me employ my work with the State of California's infrastructure strategy and the New Jersey State Plan, whose principles for large-scale infrastructure planning are instructive.

The Public Policy Institute of California commissioned an examination of infrastructure in that state. It reported on all infrastructure for all state agencies and found some eye-openers [28]. One was an outcome of the "prison-industrial complex" [29]. Among other things, we found that the State of California spent less in capital investment (facilities) per student at the University of California System that produced the most Nobel prizes in the 20th century, than per prisoner in the prisons that produced the most vehicle license plates. The prison lobby was the biggest lobby in California then [30].

Another finding was how backwards the process to finance infrastructure was, as revealed by Figure 1. The right-hand column describes the process for planning, budgeting, and financing infrastructure in California as of the year 2000. It was a budget- and finance-driven system. What got built was wholly conditioned by the money available to spend on it, rather than by actual current needs or projections of needs. Those funds were subject to/determined by political bargaining in the state legislature. The left-hand column describes an evidence-based system that follows a life-cycle method 
driven by actual and projected infrastructure needs. As one result of this research report, the State of California adopted a new law mandating five-year strategic infrastructure plans at the state level. This first-time-ever requirement for a statewide plan changed planning and budgeting, with financing slower to follow. This is a case of research informing policy and the adoption of new laws.

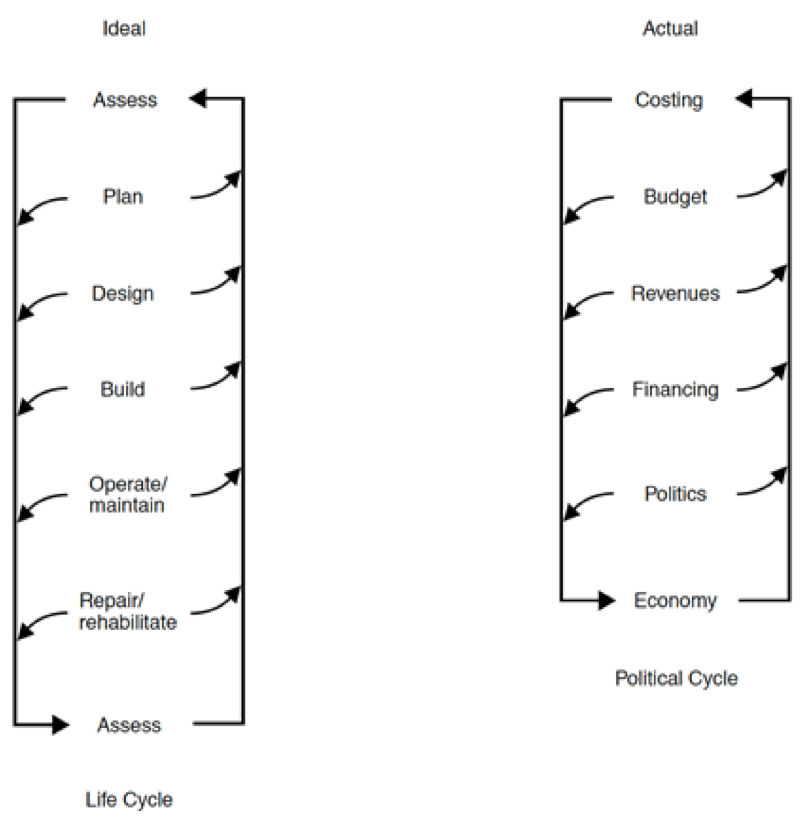

Figure 1. Life cycle and actual models of infrastructure financing and planning in California; Source from: Neuman, M.; Whittington, J. Building California's Future: Current Conditions in California's Infrastructure Planning, Budgeting and Financing. Public Policy Institute of California, San Francisco, 2000.

In the US state of New Jersey, a key component of their State Plan (initially adopted in 1992) is an Infrastructure Needs Assessment for a population then of eight million, for all public infrastructure at all levels of government-municipal, county, and state. The assessment, which covered the 20-year period between 1990 and 2010, was required by the State Planning Act of 1986. This 300-page assessment of infrastructure needs was pioneering for being the first known use of life cycle analysis and life cycle costing for entire infrastructure systems [31].

The State Plan itself was a strategic spatial plan to guide infrastructure. Significantly, like the UK's National Infrastructure Commission in the late 2010s, New Jersey's State Planning Commission was housed in the Department of Treasury. This was a political decision that took into account the inescapable link between capital funding and infrastructure facilities. Moreover, treasury is the management arm of government, coordinating policies and budgets both capital and operational for all agencies. Thus, the State Plan links politics, policy, planning, management, and budget; all based on infrastructure investments supported by the analysis in the Infrastructure Needs Assessment.

About Infrastructure Needs Assessments: The first one I read carried the ominous title America in Ruins [15]. Every one that I have examined since can be captured in three terms. First, dire warnings: of, (in)adequacy, (lack of) capacity, and safety. Second, an off-putting number of zeros follow the dollar sign or other unit of currency. Finally, need always far outstrips supply, as well as funding. This persistent parade over the last forty years suggests solutions to the problems that they bring to light have not really been forthcoming. There continue to be major funding shortfalls because we are still stuck in "business as usual", in terms of planning, systems design, network integration, and in particular, financing. The message is to better link infrastructure assessments with actual funding.

Two other instances illustrate the value of considering the regional scale in developing sustainable infrastructure solutions. One is for the Texas Urban Triangle of Dallas-Fort Worth, Houston, San Antonio, and Austin; the motor of the Texas economy. This case refers to built (gray, hard) 
infrastructures. The other is for New Orleans and Southern Louisiana, and refers to natural (green) infrastructures. The Texas Triangle contains some 20 million people, generating over $80 \%$ of the state's economy. It is a functioning urban mega-region whose name has entered the lexicon by conferring the region with a distinct identity. Work by an interdisciplinary team at Texas A\&M University on a composite suitability analysis for future development mapped over 80 factors across 58,000 square miles, or 150,000 square kilometers. This work identified the most and least suitable places for both urban development and for land conservation [32]. Among the more revealing findings was the super-imposition of several development factors that showed the great degree of risk dozens of hazardous and toxic waste disposal sites in the Houston metropolitan area were. This risk was compounded by Houston's sea level elevation, 15 feet of land subsidence at the heart of the city due to century-long water withdrawals from aquifers that were in the unconsolidated soils of the coastal plain (no solid bedrock), rising sea levels, increased flooding from tropical storms, and a greater risk of more and more severe tropical storms (hurricanes). This analysis was enabled by the regional perspective on the inter-relation of infrastructures such as waste disposal sites with the natural environment.

Follow-on research, funded by the Texas and U.S. Departments of Transportation, developed a web-based Spatial Decision Support System to analyse the most suitable and sustainable route for high speed rail in the Texas Triangle [33,34]. This report added ecological and economic factors to the regional analysis, in addition to the typical factors considered by engineers in high speed rail route siting, mainly limited to turning curve radius and slope (gradient) of the train tracks. This method demonstrated the value of multi-disciplinary and multi-scalar analysis of spatial planning informed by GIS methods in the planning of sustainable infrastructure.

The second instance refers to the regional spatial analysis for the sustainable redevelopment of New Orleans and the south coast of the State of Louisiana in the aftermath of Hurricanes Katrina and Rita in 2005 [35]. These were two of the most powerful tropical storms in recorded history [36]. The analysis and plan for recovery after the hurricane revealed that taking a regional and ecological perspective led to drastically divergent findings for the causes and solutions to storm damage and flood risk, compared to the reports prepared by individual professions such as architecture, planning and engineering. This finding evolved from learning about two inter-related regional, ecological factors. First, that the erosion and disappearance of protective barrier islands and coastal marshlands (bayous in Louisiana) was due to the 150-year long process of containing the Mississippi River's floods by earthen levees. These levees prevented coastal wetlands from being replenished naturally by the river's sediments, a natural process that had been occurring for millions of years, and which created the state's coastal wetlands. Further, the construction of "Mr. GO" - the colloquial name of the Mississippi River Gulf Outlet, a wide ship canal carved into the wetlands to enable straight passage from New Orleans to the Gulf of Mexico-had devastating impacts. This passage, intended to enable ships to avoid the meandering river and its fearsome currents at its delta, had the effect of allowing hurricane storm surges to barrel at high speed straight from the Gulf to New Orleans. In the case of Hurricane Katrina, the storm surge was 29 feet (nine meters) high, swamping the city and causing about 2000 deaths and over USD 125 billion in direct damage.

By contrast, post-Katrina reports by professional societies found other causes and responses. The civil engineers found that the earthen levees were too weak and needed to be strengthened. The architects found that the buildings were not strong enough and needed to be elevated and strengthened. The urban planners found that neighborhoods and towns were at risk, yet proposed "new urbanist" solutions of enhanced walkability and more compactness, meaning a higher density of buildings. While important, these solutions did not address the causes of devastation, and left structures, infrastructures, cities and their inhabitants completely vulnerable to future storms. To how many other extant infrastructure systems designed to efficiency standards does this conclusion apply? The devastating fires in Australia and the American West in 2019-2020 and the coronavirus pandemic of 2020 drastically bring to the fore the need for new approaches, and new metrics for resilience and sustainability to be applied to their design, planning, and management. 
For example, we calculated that the distance between New Orleans and the Gulf Coast was the same distance over which the storm surge would have been attenuated had the wetlands and barrier islands remained intact. In other words, the ecological services provided by intact natural habitats (coastal wetlands) would have prevented flooding, sparing lives and property damage. In this case, these natural coastal habitats served as "green infrastructure", although the terms are not directly interchangeable. Another multi-factor and large-scale regional GIS-based spatial analysis demonstrated the vital importance of ecological infrastructure in protecting disadvantaged populations (low income, low education). The analysis found that these populations were more vulnerable, both in the city of New Orleans as well as in rural areas, than wealthier and more educated residents. Overall, we found that the root causes of flooding and related damage were regional and ecological, not local and technical, per the architects and engineers. This was due to our interdisciplinary and ecological approach.

\section{Redefining Smart Infrastructure}

This smart use of nature as green infrastructure is a less costly, less damaging, and more sustainable way to manage ecosystems and urban development simultaneously. It synthesises environment and development. This enables a new approach to infrastructure development. In the past, we tended to think of infrastructure as the hard stuff, the grey matter, as if that was all that mattered. Yet is this mentality and the methods and systems that it spawned smart? How much urban infrastructure is concrete and asphalt, the dumbest materials around? While much of the activity around so-called smart infrastructure has centered around sensing, software, apps, programming, and artificial intelligence as portrayed by the private sector consulting and technology firms, in my view smart infrastructure is smart thinking about infrastructure. This means integrating the natural and built environments. What provides the "smart" is the human brain, intelligently applied.

In contrast to hard urban infrastructure, take a quintessential terrestrial ecosystem-a forest. We know how alive, diverse, beautiful, productive, and complex they are above ground. Let us go underground, to examine the complex root systems of forests-its infrastructure. Mycorrhizal, fungal, and root networks in forest soils comprise nature's infrastructure. They underpin and give life to the forest. Underground mycorrhizal networks channel the symbiotic relationships between undersoil fungal networks and the roots of all vascular plants, including trees. In fact, the two largest known organisms on the planet are largely underground. Both are clonal colonies with massive roots. A honey fungus, Armillaria solidipes, in Oregon covers 3.7 square miles. A quaking aspen colony, Populus tremuloides, in Utah has a unified root system for 47,000 trees. Estimates put it at 80,000 years of age, making it the oldest organism known. Tree species go back hundreds of millions of years. All thanks to roots, nature's infrastructure.

Trees communicate with each other and provide life support to each other through these networks, as if they were a close-knit family $[37,38]$. Fungi do this too. These networks form the basis of forest ecosystems [39]. They have been around for hundreds of millions of years (The oldest known tree species is Wattieza, 380 million years old. The oldest known living tree species is the ginkgo biloba, estimated at 270 million years. Trees are the oldest clonal and non-clonal living beings on the planet today, at 9,500 years for a Norway spruce in Sweden and 5,000 years for a bristlecone pine in California, respectively.) What about urban ecosystems? Are urban infrastructures that smart? Can they talk to and support each other, self-regulate, self-regenerate, and create resilience? We need to move far beyond the criteria of function and efficiency that have dominated infrastructure and cities for centuries. To be fair, forests have had a several hundred-million-year evolutionary head start on cities. Hopefully humans will have the time to catch up.

Trees are not the only ancient beings that communicate via roots. Fossils of the Ediacaran macrobiota (about 550 million years old) record diverse marine palaeolithic communities, including early animals, which pre-date the Cambrian Explosion. This group of aquatic species, called Rangeomorpha, were resilient and "dominated deep-marine ecosystems" of that era. These fossils have been found world-wide. They had abundant filaments (root-like structures) that occurred in a dense 
network pattern that could extend up to several meters. The filaments constituted a prominent component of their ecosystems, and connected up to seven different species in what could have been colonies [40]. The "extant fossil record suggests that Ediacaran (species) were likely clonal networks" [40]. The filaments served as channels for nutrients and chemical signals: "a means to communicate between the organisms," according to Liu in an interview in the New York Times on 12 March 2020 [41]. The lesson is that nature has long used living" infrastructure networks" to support and nurture itself. These were more than mere circulatory systems. They had sentient, communicative, and intelligent properties involved in self-regulation as they formed living communities and ecosystems. There are principles that humans can learn and adapt into human infrastructure networks as we seek to become more sustainable.

To extend this analogy into the human realm, it is helpful to look at a circular economy. Its basis, unsurprisingly, is circular infrastructure, including circular logistics and productiondistribution-consumption-reuse networks, abetted by circular thinking. Circular infrastructure networks are open, interconnected, and integrated, where the outputs of one form the inputs to others (which is why referring to "closing the loops", as proponents advocate, is actually incorrect. In nature, the loops always remain open). A key part of their openness is being open to new information and learning. This refers to the human element, embodied in a new type of governance and urban management. This is a tall order given the way infrastructures have been designed, built, and managed till now.

\section{Scale and Modularity}

We can go further to highlight the role of small-scale infrastructures that complement yet are overshadowed by "big ticket" megaprojects. Gargantuan megaprojects have equally gargantuan price tags and environmental and social impacts. Just to use some current projects (year 2020) in the United Kingdom as examples: GBP 50 billion for a Railways Upgrade Plan, GBP 30 billion and GBP 60-100 billion estimates, respectively, in today's terms, for one London metro line (Crossrail 2) and high speed rail from London north to Manchester and surrounding cities (HS2). A recently completed single metro (underground) line in London, Crossrail 1, is expected to total GBP 20 billion when complete in 2022 (Crossrail 1 and 2 cost estimates obtained from their respective web sites at the time of this writing, March 2020. www.crossrail.co.uk). The Thames Tideway Tunnel, a single "super sewer" of just a few miles long, is expected to open in 2023 and cost GBP 5 billion. For cities nowadays, individual large-scale, centralised infrastructures, such as transport, sewerage, solid waste, water supply, and energy systems each typically have capital costs of upwards of billions of dollars/pounds/euros. Hundreds of millions are added annually for operations and maintenance.

On the other hand, nature's infrastructures, also referred to as nature services, are virtually free, and mostly free of upkeep and maintenance, when humans do not disrupt them [42]. Nature is organised in ecosystems supported by numerous natural networks. Most individual units of nature, especially beings, aggregate in scale in modular and incremental ways to form habitats, communities, and ecosystems. It is their characteristics, and the operating principles behind them, that are illustrative for infrastructure today. These characteristics are diametrically opposed to those of linear, rational infrastructure systems designed by engineers, as Figure 2 shows. Let us look at what this could mean for 21st century infrastructure-truly smart infrastructure.

We can use the example of a tree once again, at least by analogy. A tree has two major cycles, seasonal and life, both involving countless other organisms in its cosm. A tree is a paragon of permanence and continuity, lasting centuries if not millennia, and providing stability to its surrounds.

One of humanity's great metaphors is the tree of life. Epics and legends extol the role of the tree, as symbol and as fact. The tree is the archetype of the web of life.

Trees also exemplify the dialectic of continuity and change, standing erect for centuries, shedding leaves over seasons, rotting back to the soil over years. Trees are flexible as they sway in the wind. They are resilient as they absorb the rain. The provide shelter, shade, food, materials, playgrounds, 
store carbon, bind the soil; the list seems endless. Tree root system interactions with soil generate enormous biological complexity. Up to 15,000 different species live in a cubic foot of soil. Trees are modular units that network to make forests, apex ecosystems that are central to life itself, including that of the planet's earth system. Trees through their roots filter out an incredible variety and quantity of toxic chemicals. Trees create microclimates and are indispensable to the global climate and Gaia herself. Trees produce their own energy and collect their own water using the intelligence of evolution. A tree in conjunction with its surroundings recycles its own litter and itself, fulfilling its life cycle while providing for countless others besides. Trees are open systems connected to other open systems through multiple natural networks, nature's infrastructures. These are the characteristics and operating principles that can be adapted to infrastructures.

\section{INFRASTRUCTURE CHARACTERISTICS}

$\begin{array}{ll}\text { OLD / CURRENT } & \text { NEW / FUTURE } \\ \text { centralised } & \text { distributed } \\ \text { tixed } & \text { mobile } \\ \text { inflexible } & \text { flexible } \\ \text { rigid } & \text { adaptable } \\ & \\ \text { large scale } & \text { small scale and modular } \\ \text { expensive } & \text { inexpensive } \\ \text { risk prone } & \text { resilient } \\ \text { isolated } & \text { integrated }\end{array}$

Figure 2. Old versus new infrastructure characteristics.

Asking the right question is more important than having the right answer. You can have what you think is the right answer, but if the question is wrong, the consequences can be disastrous. Just ask the residents of New Orleans after Hurricane Katrina in 2005, or Fukushima after the earthquake and tsunami in 2011.

In this spirit, why must a building consume energy? Why can a building not produce energy? Why must a building consume water? Why can a building not provide its own water? Why can a building not recycle its own outflows? Why can a building not be like a tree? Can we design buildings, infrastructures and cities to be as smart as trees? That is, can we be as smart as a tree?

Using this thinking, for small-scale and modular infrastructures, also implies applying "last mile" thinking to all infrastructures, so that they interconnect with all points of a city, just as capillaries and venules are connected to arteries and veins to serve all cells in the body. Last mile, last drop, last bit (or byte), last joule, and so on.

When infrastructures are designed and built so that smaller scale networks are incrementally interwoven into larger ones, their modular components are incrementally embedded in larger scales. This endows flexibility, resilience, and adaptability. It allows for easier and cheaper network expansion, upgrades, and modifications, as well as adopting or retrofitting advances in technology. Thus, they are better able to serve changes in populations, their demographics, and their needs. These micro-systems are less costly and can be deployed on each building or each space, unobtrusively and attractively. They include small rotary wind turbines, solar panels, rainwater tanks, green roofs, compost gardens, and so on. Our artists and designers are more than up to the task, given a chance to collaborate. A fully green building with its own, self-contained infrastructure, can approach one hundred percent sustainability. They also can feed into or obviate the need for expensive, large-scale systems. Small-scale, modular infrastructures can be, and are, funded by users, small-scale investors, and individuals via micro-financing and crowd-sourcing precisely owing to their small scale and modularity. This plug and play approach contrasts sharply with large-scale and centralised systems that take years if not decades 
to plan and build, and become a burden to the public purse, the citizenry, and nature. Moreover, centralised megaproject infrastructures make us dependent, rather than aware of and self-reliant regarding daily life. Home- and building-based micro-systems, while not feasible in every instance, go a long way in educating about sustainability.

Developing modular, small-scale and decentralised nodes of infrastructure that are interconnected to form integrated networks is less costly, more sustainable, more equitable, and more feasible because they are able to be more easily retrofitted into the existing cities and regions. We already do this with the internet and smart devices. Why not translate that to other networks?

\section{Infrastructure Finance}

We can also apply the circular approach to funding. Life cycle funding may be the most important missing link in solving the infrastructure finance conundrum. We can look to the past to remind us of the role of finance in infrastructure and city building, always foundational. We use an emblematic city-London-as a guide. In its evolution to world city, London shows the pivotal confluence of finance capital with infrastructure. Like Rome two millennia ago, all roads led to London, as well as rails and ships. Without discounting the roles of Liverpool, Manchester, Glasgow and fellow cities at start the industrial revolution and the rise of the British Empire; it was London where the greatest merger of finance and transport made its mark in transforming London into the first global city, and not incidentally, knowledge capital. Financiers such as Frankfurt banker Nathan Mayer Rothschild arrived in London and set up a banking house in the city in 1798. He was aided by a large sum of money given to him by his father, Amschel Mayer Rothschild. This bank financed numerous large-scale projects, including railways and the Suez Canal [43].

London was not alone. New York and Chicago followed as first in the new world to apply this "tale of two capitals" formula. The two capitals being finance and facilities, always married. Historian William Cronon's magisterial Nature's Metropolis (1999) described how the marriage of these two capitals made Chicago and transformed much of the American continent besides [44].

Historically, most funding for infrastructure worldwide has been only to pay for the capital costs of construction. Taxes, tolls and user fees were presumed to take care of operations and maintenance. Some funds were dedicated, many were not. Most did not keep pace with inflation, much less demand. Expenditures beyond operations and maintenance that are part of a cradle-to-cradle life cycle fell outside of standard funding mechanisms. Yet capital costs represent only a portion of the life cycle of costs for an infrastructure system or network. Funding capital costs only is now in question. No matter the source, the amount needed and what it is needed for must be calculated in an entirely new way. Business as usual-funding capital costs only—digs the holes we have already dug in terms of chronic underfunding even deeper. Another way to further this approach is to marshal the theory of degrowth [19]. Degrowth is a critique of the notion that economic growth is necessary for economic vitality and stability. Instead, degrowth argues that economic growth is too damaging to continue to be useful. Growth for growth's sake is a cancer and in human terms is not sustainable. Advocates of degrowth suggest transforming economies so that they produce and consume less, and thus are more sustainable.

While the private sector has long been involved in infrastructure and its financing, around 1980 this activity accelerated. Several new factors came in to play at that time. First, neoliberalism took hold, with governments at all levels in many countries suffering budget and therefore service cuts, including infrastructure. Into this breach stepped the private sector, offering its presumed expertise and efficiency. This trend has continued to this writing, forty years since. Second, the deregulation of the financial industry further enabled firms and funds to enter the infrastructure and public sector space. Third, the World Bank, the International Monetary Fund, and related regional development banks supported both of these trends with research, publications, technical assistance, and mainly, loans. Fourth, the complexity of infrastructure, and the focus on individual mega-projects rather than networks or systems, has led to the twin components of extremely complex contracts governing their planning, 
construction and operations; and new institutional mechanisms to manage them-public-private partnerships. Finally, continuing deregulation of and creativity in the financial sector has led to a wide range of funding/financing instruments. These new partnerships and their financing instruments largely benefit the private sector by accruing the bulk of the returns on investment, and prejudice the public sector by transferring most of the risk to it. Thus, it is easy to grasp why the private sector, particularly finance, now abetted by management consulting and high technology firms, has muscled its way onto infrastructure turf. The increasingly superior returns on finance capital compared to other types of capital, on top of multi-trillion pound worldwide infrastructure spending go a long way in explaining the ascendance of infrastructure in equity arenas. Infrastructure investments are returning lucrative yields. The old situation of government paying for it all is gone. What will replace it that will be both sustainable and equitable in serving the public good?

\section{The Public Good}

To make sure that the public interest remains served in this bold new world, value capture for infrastructure finance becomes paramount. That is a tall order in debilitated government regimes after forty years of neoliberalism and austerity. Private equity prefers government to keep its hands off infrastructure, especially now that bond and cash yields are nearly non-existent and equities are risky. This is paradoxical, as private equity and real estate developers at the same time seek certainty, which in large part is guaranteed by strong and stable government, and the infrastructure it provides. Can society have it both ways? More to the point, can the short-sighted private sector have its cake and eat it too?

This debate is critical, and must go on. I believe it can best be informed and brokered by impartial institutions, such as universities and non-governmental organisations, and carried out dispassionately in independent fora and arenas. All sectors have their proper roles to play. Yet one sector cannot abdicate responsibility for infrastructure, and another sector cannot usurp it due to a single motive. Balanced partnerships in which multiple interests are served fairly are the aim. This used to be the job of government, providing public services that benefitted all.

Regardless of how financing is obtained, what it pays for and how those decisions are made are also of import. In this case, "what" does not mean which systems or projects, like which airport will get a third runway or which type of energy will be funded. Existing mechanisms have those decisions more or less sorted, though we can always do with more transparency, evidence, and civic input. Instead, we need to devise new decision criteria based on a cradle-to-cradle life-cycle, equity, and sustainability.

We must be fully aware of the implications in this challenge. It could be called Old Habits Die Hard, Sunk Capital [45] Dies Harder. The fixed costs of sunk capital and the fixed facilities it builds determine urban form and function, as they have for millennia. Those fixed forms, roads and rails, ports and parks, and so on, are priceless assets of the public trust, and civic works of art at their very best. Yet are these old, centralised system designs truly sustainable and resilient long in to the future? Can we transform equally fixed and discipline-bound methods? Where professions compete for and resolve conflicts regarding turf? Professional habits die hard too. Who would have thought Bruce Willis to be a philosopher of infrastructure?

\section{Infrastructure, Growth, Progress, and Sustainability}

Today, as society demands new types and arrangements of infrastructure to correspond to new needs like mobility, speed, agility, big data, the cloud, virtual reality, artificial intelligence, and so on; is it not finally time to employ our intellectual capital to innovative thinking for infrastructure capital as well? As one of the biggest, fastest growing, and most lucrative sectors of the economy, particularly finance, surely infrastructure merits the best thinking of the private sector. However, rather than a call for unfettered capitalism, unregulated markets, indiscriminate techno-fixes, and a private sector takeover of public services; instead a caution about the necessary link between infrastructure and 
urban development. In the will to growth, which leads to the will to infrastructure, we find a logic not dissimilar to the will to power, with its inevitable consequences, especially conflict. Degrowth addresses this.

Take the London Plan and its cautionary section titled "A Changing Climate". Yet the very next page sports a section heading "Ensuring the Infrastructure to Support Growth" [46]. We are alert to the cognitive dissonance of reading those two sections in the London Plan back to back. Environment and development have long been considered in opposition. A key premise for Crossrail 2 metro project in London, for example, is to support projected growth of 200,000 homes and 200,000 jobs [47]. While there has been progress in making the environment and development more compatible since the Brundtland Report's clarion call for sustainability [48], the aggregate data worldwide show that we are going backwards on climate change. This reveals that development still takes a priority over nature and a toll on the planet. It also suggests a tremendous opportunity for infrastructure to help turn the tide, instead of merely serving to catalyse urban and economic growth.

A conversation leading to serious action to unlock the opportunity hiding behind this conflict awaits. Despite all the IPCC reports, climate accords, scientific research, climate protests, and so on; the main drivers of climate change-population growth, fossil fuels, and increases in per capita consumption, are far from abating, as all the data show. Any sober analysis-and there have been many-clearly shows that we cannot escape a fundamental rethink of growth and progress if we seek to remain on a habitable planet. Yet I posit that we can maintain quality of life and well-being even as population grows, if we do it right, and right away. One indispensable key is sustainable infrastructure.

In a series of articles, I have demonstrated the scientific principles and theories along with mathematical proofs that underpin the mounting empirical evidence that shows that as cities become larger and more complex, they can only continue to become ever more unsustainable. This is due to the immutable laws of thermodynamics [49-52]. That is, unless we model cities and infrastructures on evolutionary and ecological principles. We cannot buy our way out of this predicament using new or more technology, mainly because spending and consuming according to existing ways (business still as usual) have led us into it. We can think our way out, however. If we think and then act in a new way.

This new thinking entails sustainability. Strictly speaking, sustainability refers to the degree to which a process is sustainable, that is, can be maintained over the long run without depleting the resources, ecosystems that support it, and without exceeding the capacities of natural systems and the planet as a whole to absorb the impacts of the process. Thus, sustainability refers to processes, not things or places.

Today more than ever, rigid disciplinary thinking is called into question in the network society and the space of flows. What is the future of infrastructure when we recognise the primacy of processes in determining urban form? We live transactive lives on the go in transactive cities, presaged by urban theorist Richard Meier's 1968 article "The Metropolis as a Transaction-Maximising System" [53]. Transactions enabled by infrastructure. One beacon forward to greater sustainability is to recognise that these transactions are processes, and these processes become the basis for the design of sustainable infrastructure networks and the cities that they undergird.

\section{The Public Trust}

Long ago, infrastructure and public or common lands were known as the Public Trust. Another historical term for the material public trust-lands and other common goods-was commonwealth. Wealth that was held in common, by the people who were its owners, through the trust they placed in their representatives in government. How different it is today.

In recent decades there has been a steady, incremental, drip by drip erosion of the Public Trust, meaning public lands and public works (infrastructure) in today's terminology. This is but one consequence of neoliberalism. 
It is revealing to note the terms in use today-public capital, asset, and investment-that have replaced what was called the Public Trust. The terms have changed over time so that private sector language dominates now.

Another facet of public trust is that it serves as the glue holding messy democratic processes together. This aspect of trust is embedded in social and political capital that keeps people engaged constructively over the long periods of time needed to accomplish infrastructure planning and financing. This glue consists of two inter-related ingredients: trust and transparency. Otherwise, no matter how carefully constructed the process, how cordial the proceedings, how fair the deliberations, and how carefully selected the stakeholders; any process could fall apart without public trust. Interpersonal trust is not sufficient. The erosion of this facet of the public trust has been most damaging to our collective responsibility to plan and finance infrastructure, and to ensure its services and impacts are equitable. For sustainable infrastructure to be planned and financed responsibly, civic trust needs to be rekindled.

Many cities around the world have poured vast sums into revitalising their material public trusts to enhance their cities and their citizens' lives. European cities, for example, having been doing this by focusing on waterfronts and parks, public spaces such as plazas and squares, and civic places such as libraries and cultural centers. By so doing, they have been truly transforming their cities, and their citizens' relationships to them. They have been reinforcing the second aspect of public trust mentioned above — civic mindedness—-by creating higher quality material public trust—infrastructure. This mutually reinforcing relationship is vital for civic life to flourish. The London Plan, for example, makes much of revitalising the River Thames so it once again animates "a city that delights the senses". Yet European cities are not alone. Infrastructure improvements on a big scale have been bread and butter for city competitiveness for two generations.

\section{The Sharing Economy, Public Trust and Infrastructure}

To conclude, we bring another aspect of the emergent circular economy into the realm of infrastructure-the sharing economy. Its distinction is trading on use value, not exchange value. Use value as an underlying principle places it properly in the realm of ecology instead of economy, notwithstanding their common root in Greek, oikos. This is because exchange is a relationship among partners. An exchange is an individual process that, when their flows are aggregated, yields an ecosystem of interacting individuals (critiques for sharing corporations such as ride-sharing and home-sharing, and their effects on cities and citizens are numerous [54-56]. My comments refer to the ideal, which would need to be planned, managed, and regulated to avoid or minimise negative effects). This model of a sharing economy is part of a greater sharing ecology, which is undergirded by mutual trust in our fellow citizens. In this way, individuals in a sharing economy perform formerly public services for a fee. We could simply call this sharing ecology either society, or community [57].

We can craft multiple roles for new infrastructures in the sharing society. The new vision of smaller, modular, decentralised, and distributed networks suits the inter-personal nature of caring and sharing. This form of infrastructure, digitally enabled, helps bring out the best in us. Apps devised for distributing food waste and for enabling assistance during disasters or epidemics are but two demonstrations of the possibilities afforded by ingenuity and by reconceiving public services as small-scale and interpersonal rather than large-scale and institutional. What is more, this type of infrastructure can go a long way in gaining greater social equity and distributive justice. Let us not overlook that sharing is caring. We can also grasp the benefits to democracy that stem from extending the sharing society. This is because cooperation is a key precept in society, heightened by caring and sharing.

As we know, infrastructure is paramount to all of us. New kinds of infrastructure for new ways of living can lead us into a bold new world that is not ominous like Huxley's. The aim is to shape thinking and institutions so that infrastructure is not seen merely as a physical substrate to buoy the 
economy. Infrastructure has ramifications in every realm of human life, and can lift the human spirit. The Golden Gate bridge does that for me every time.

Infrastructures enable cities to prosper and grow. They are key to their sustainability and our well-being. As infrastructure made cities possible, great infrastructure makes great cities possible, and sustainable infrastructure makes sustainable cities. This applies to towns and villages as well as cities; indeed to nations and economies. Think of Industrial Britain and you think railways. Preindustrial Britain and canals. Global Britain and networks. Great infrastructure makes great places. Continuing to do so into the future, we will be proud to be "citizens of somewhere". Somewhere special, in part made so by infrastructure.

Funding: This research received no external funding.

Conflicts of Interest: The author declares no conflict of interest.

\section{References}

1. Aerts, J. Adaptation cost in the Netherlands: Climate change and flood risk management. Clim. Res. Neth. 2009, 34-44.

2. Alberti, M. Cities That Think Like Planets: Complexity, Resilience, and Innovation in Hybrid Ecosystems; University of Washington Press: Seattle, WA, USA, 2016.

3. Lambeck, K.; Esat, M.; Potter, E.-K. Links between climate and sea levels for the past three million years. Nature 2002, 419, 199-206. [CrossRef] [PubMed]

4. Rohling, E.; Fenton, M.; Jorissen, F.; Bertrand, P.; Ganssen, G.; Caulet, J.P. Magnitudes of sea-level lowstands of the past 500,000 years. Nature 1998, 394, 162-165. [CrossRef]

5. Kopp, R.E.; Simons, F.J.; Mitrovica, J.X.; Maloof, A.C.; Oppenheimer, M. Probabilistic assessment of sea level during the last interglacial stage. Nature 2009, 462, 863-867. [CrossRef] [PubMed]

6. Dutton, A.; Lambeck, K. Ice volume and sea level during the last interglacial. Science 2012, 337, 216-219. [CrossRef] [PubMed]

7. Kulp, S.; Strauss, B. New elevation data triple estimates of global vulnerability to sea-level rise and coastal flooding. Nat. Commun. 2019, 10, 1-11.

8. Anand, N.; Gupta, A.; Appel, H. (Eds.) The Promise of Infrastructure; Duke University Press: Durham, NC, USA, 2018.

9. Giovannini, R. Venice and MOSE: Story of a Failure; La Stampa: Turin, Italy, 2017. Available online: https://www.lastampa.it/esteri/la-stampa-in-english/2017/10/12/news/venice-and-mose-story-of-afailure-1.34401212 (accessed on 9 October 2020).

10. Saemangeum Seawall. Available online: https://en.wikipedia.org/wiki/Saemangeum_Seawall (accessed on 3 March 2020).

11. Reuss, M.; McPhee, J. The control of nature. Technol. Cult. 1991, 32, 405. [CrossRef]

12. Sassen, S. The Global City: New York, London, Tokyo, 2nd ed.; Princeton University Press: Princeton, NJ, USA, 2000.

13. Boyden, S.; Millar, S.; Newcombe, K.; O'Neill, B. The Ecology of a City and Its People: The Case of Hong Kong; Australian National University Press: Acton, Australia, 1981.

14. Kane, J.; Tomer, A. Shifting to an Era of Repair: US Infrastructure Spending Trends; Brookings Institute: Washington, DC, USA, 2019.

15. Choate, P.; Walter, S. America in Ruins: The Decaying Infrastructure; Duke University Press: Durham, NC, USA, 1981.

16. American Society of Civil Engineers ASCE. America's Infrastructure Report Card; ASCE: Washington, DC, USA, 2016.

17. Armitt, J. Civil engineers: Shaping ourselves and our world. Proc. Inst. Civ. Eng. 2016, 169, 3-8. [CrossRef]

18. Neuman, M. The Power of Infrastructure that Shapes Spatial Strategy-Who is Left Behind? Town Plan. Rev. 2020, 95, 485-497.

19. Neuman, M. Collaborative and Interdisciplinary Design Education. In Ingeniería, Urbanismo y Universidad. Homenaje a José María de Ureña; Coronado, J.M., Solis, E., Eds.; E.T.S.I. de Caminos, Canales y Puertos: Madrid, Spain, 2020. 
20. Kallis, G. Degrowth; JSTOR: New York, NY, USA, 2018.

21. Harari, Y. Sapiens: A Brief History of Humankind; Harvill Secker: London, UK, 2014.

22. UNEP United Nations Environment Programme. Global Material Flows and Resource Productivity; United Nations Environment Programme: Paris, France, 2016.

23. World Wildlife Fund. Living Planet Report 2018: Aiming Higher; WWF International: Gland, Switzerland, 2018.

24. Steffen, W.; Grinevald, J.; Crutzen, P.; McNeill, J. The anthropocene: Cultural and historical perspectives. Phil. Trans. R. Soc. A 2011, 369, 842-867. [CrossRef]

25. Kunkel, B. The Capitalocene. Times Rev. Books 2017, 35, 1-13.

26. Malm, A. Fossil Capital: The Rise of Steam-Power and the Roots of Global Warming; Verso: London, UK, 2015.

27. Infrastructure, Environment, and Life in the Anthropocene; Hetherington, K., Ed.; Duke University Press: Durham, NC, USA, 2019.

28. Neuman, M.; Whittington, J. Building California's Future: Current Conditions in California's Infrastructure Planning, Budgeting and Financing; Public Policy Institute of California: San Francisco, CA, USA, 2000.

29. Schlosser, E. The Prison-Industrial Complex. The Atlantic, December 1998; pp. 51-69.

30. Page, J. The Toughest Beat: Politics, Punishment, and the Prison Officers Union in California; Oxford University Press: Oxford, UK, 2011.

31. New Jersey State Planning Commission. Assessment of Infrastructure Needs to 2010 for the New Jersey State Development and Redevelopment Plan; New Jersey State Planning Commission: Trenton, NJ, USA, 1992.

32. Neuman, M.; Bright, E. (Eds.) Texas Urban Triangle: Framework for Future Growth; Outhwest Universities Transportation Consortium: College Station, TX, USA, 2008.

33. Kim, H.Y.; Wunneburger, D.; Neuman, M.; An, S.Y. Optimizing high-speed rail routes using a Spatial Decision Support System (SDSS): The Texas Urban Triangle (TUT) case. J. Transp. Geogr. 2014, 34, 194-201. [CrossRef]

34. Kim, H.Y.; Wunneburger, D.; Neuman, M. High-speed rail route and regional mobility with a raster-based decision support system: The Texas Urban Triangle case. J. Geogr. Inf. Syst. 2019, 5, 559-566.

35. Rebuilding a Sustainable Gulf Coast: A Regional Plan for New Orleans and Environs; Neuman, M., Ed.; College Station: Texas, TX, USA, 2007.

36. Landsea, C.; Anderson, C.; Bredemeyer, W.; Carrasco, C.; Charles, N.; Chenoweth, M.; Clark, G.; Delgado, S.; Dunion, J.; Ellis, R.; et al. Documentation of Atlantic Tropical Cyclones Changes in HURDAT; National Oceanographic and Atmospheric Agency, Atlantic Oceanographic and Meteorological Laboratory: Miami, FL, USA, 2013.

37. Simard, S.; Vyse, M.; Larson, A. Meta-networks of fungi, fauna and flora as agents of complex adaptive systems. In Managing forests as complex adaptive systems: Building resilience to the challenge of global change; Puettmann, K., Messier, C., Coates, K., Eds.; Routledge: London, UK, 2013; pp. 133-164.

38. Wohlleben, P. The Hidden Life of Trees: What They Feel, How They Communicate; Greystone Books: Vancouver, BC, Canada, 2016.

39. Gorzelak, M.A.; Asay, A.K.; Pickles, B.; Simard, S.W. Inter-plant communication through mycorrhizal networks mediates complex adaptive behaviour in plant communities. AoB Plants 2015, 7. [CrossRef]

40. Liu, A.G.; Dunn, F.S. Filamentous connections between ediacaran fronds. Curr. Boil. 2020, 30, $1322-1328$. [CrossRef]

41. Has Australia Reached a Climate Tipping Point? New York Times, 24 February 2020.

42. Costanza, R.; D'Arge, R.; Raskin, R.G.; Sutton, P.C.; Belt, M.V.D.; De Groot, R.; Farber, S.; Grasso, M.; Hannon, B.; Limburg, K.; et al. The value of the world's ecosystem services and natural capital. Nature 1997, 387, 253-260. [CrossRef]

43. Hirschhorn, B.; Ferguson, N. The house of Rothschild: Money's prophets, 1798-1848. Hist. Teach. 2000, 34, 129. [CrossRef]

44. Cronon, W. Nature's Metropolis: Chicago and the Great West; W. W. Norton: New York, NY, USA, 1991.

45. Moore, J. Capitalism in the Web of Life: Ecology and the Accumulation of Capital; Verso: London, UK, 2015.

46. Mayor of London. The London Plan: The Spatial Development Strategy for London; Mayor of London: London, UK, 2016.

47. Mayor of London. The London Infrastructure Plan 2050; Mayor of London: London, UK, 2014.

48. United Nations. Our Common Future; Oxford University Press: Oxford, UK, 1987.

49. Neuman, M.; Churchill, S.W. A General process model of sustainability. Ind. Eng. Chem. Res. 2011, 50, 8901-8904. [CrossRef] 
50. Neuman, M. The compact city fallacy. J. Plan. Educ. Res. 2005, 25, 11-26. [CrossRef]

51. Neuman, M.; Churchill, S.W. Measuring sustainability. Town Plan. Rev. 2015, 86, 457-482. [CrossRef]

52. Neuman, M. Infrastructure planning for sustainable cities. Geogr. Helvetica 2012, 66, 100-107. [CrossRef]

53. Meier, R. The metropolis as a transaction-maximising system. Daedalus 1968, 97, 292-313.

54. Calo, R.; Rosenblat, A. The Taking Economy: Uber, Information, and Power. SSRN Electron. J. $2017,117$. [CrossRef]

55. Graham, S.; Marvin, S. Splintering Urbanism: Networked Infrastructure, Technological Mobilities, and the Urban Condition; Routledge: London, UK, 2001.

56. Fay, M.; Lee, H.I.; Mastruzzi, M.; Han, S.; Cho, M. The Trillion Mark.: How Much Countries are Spending on Infrastructure; The World Bank: Washington, DC, USA, 2019.

57. Congressional Budget Office of the United States. Federal Investment 1962-2018; Congressional Budget Office: Washington, DC, USA, 2019.

(C) 2020 by the author. Licensee MDPI, Basel, Switzerland. This article is an open access article distributed under the terms and conditions of the Creative Commons Attribution (CC BY) license (http://creativecommons.org/licenses/by/4.0/). 